\title{
Modeling illumination on the retina of the pilot's eye during piloting in complicated meteorological conditions in MATLAB environment
}

\author{
Yu. Kvach, \\ National Aviation University \\ Ukraine \\ E-mail: juli_k74@ukr.net
}

\begin{abstract}
The modeling of fragments of a light-signal picture in the conditions of a sharp time deficit at the stage of visual piloting of an aircraft in complex meteorological conditions is considered. It is proposed to identify potential risks through modeling in the MATLAB environment, so that in case of necessity to toke measure for reduction of occurrence probability of aviation event due to a management by reliability of the light-signal providing. A tool is proposed for modeling the illumination on the retina of pilot's eye from aerodrome fires in the MATLAB interface, taking into account the coordinates of observer, meteorological conditions and of adjacent efficiency aerodrome fires for management possibility by a risk with reducing it to an acceptable level in order to prevent aviation events. The presented toolkit in the MATLAB environment takes into account the factors influencing the observation during the visual search of aerodrome fires of light signal systems from the meteorological range of visibility, which shortens the time to determine the illumination created on the retina of the eye from the aerodrome fire, as well as determine the contribution of remote light sources for general information to get the pilot's visual sensations during approach in difficult meteorological conditions. The metric of the pilot's visual sensations during the approach in difficult meteorological conditions remains actual problem. Therefore, it is possible to simulate a light-signal picture in the MATLAB interface for the convenient use of tools for determining the visual search of aerodrome fires at civilian aerodromes, taking into account coordinates of the observer approach during and the atmospheric transparency.
\end{abstract}

Key words - observation, modeling of fragments of a light signal; visual search, recognition of lights at the aerodrome, reliability of light and signal support, risk management, probability of an aviation event, illumination on the retina, visual sensations, operability of aerodrome lights, acceptable level, difficult meteorological conditions, dominant factors, meteorological visibility range.

\section{INTRODUCTION}

The urgency of the safety of aircraft flights comes to the fore, because each aviation event gets a great resonance in society and is associated with large material losses for air carriers and aerodromes.

The experience of investigating aviation events indicates the need to apply a system approach to the problem of flight safety in order to prevent aviation events.

The statistics show that most aviation events occur at the stage of visual piloting, namely during the approach of the aircraft, or on the flight. Visual piloting is the most difficult phase of the flight, since the load of the aircraft crew at this stage is maximal. In flight mode, the pilot performs the functions of the supervisor, while the main control actions are performed by on-board equipment. During visual piloting, the pilot constantly receives data from various sources, processes them and gives out commands - all this happens in a three-dimensional environment that is constantly changing, and in a time-deficit conditions. The pilot experiences a particular load at the approach stage, ie at the end of the flight, when fatigue is felt through sound loading, vibration, psychological pressure, etc.

It is from the decision-height after establishing a visual contact, the flight is carried out guided by ground landmarks, which are the fires of the light-signal system of the aerodrome. If, at the time of establishing the visual contact, the light signal system will be in a state of refusal, the crew will not be able to establish its position in the air with respect to the runway, or visual contact may be erroneous.

\section{OVERVIEW OF EXISTING CLASSIFICATION SYSTEMS}

Current normative documents [1] give recommendations for the determination of the limiting illumination values on the retina of the eye and the law on determining the visibility range taking into accounts the complex meteorological conditions.

The circular ICAO [2] contains instructions on the practice of observing the range of visibility in the runway and the transmission of information about it with specified unresolved questions regarding the total effect of a set of lights caused by their fusion through the intervals and angles under which they are observed by the pilot.

\section{PROBLEM STATEMENT}

According to the standards of the International Civil Aviation Organization (ICAO), the landing of airplanes in terms of difficulty is divided into three operational categories (I, II, III), each of which has a certain range of visibility on the runway and decision height at landing $[1,2]$. In fig. 1 it is proposed developing visual contact with the ground in the process of decline in according to the III category for the visibility of runway less than $400 \mathrm{~m}$ and the angle of glissade $3^{0}$.

The visible area of the earth's surface is limited on the one hand by the angle of the screening of the ground by 
frame glazing airplane cabin (150), and on the second hand by the range of visibility of fires. Visual contact is considered to be reliable if the pilot sees at least $150 \mathrm{~m}$ of the earth's surface or its landmarks (fires) [2]. As can be seen from Fig. 1, the first visual contact occurs in these conditions on height of $50 \mathrm{~m}$ when in the field of view of the pilot at night the external part of the approaching fires reaches $900 \mathrm{~m}$ from the start of the runway. As the glide path decreases, the visual area of the fires increases and reaches its maximum magnitude of about $400 \mathrm{~m}$ at the moment of contact.

The image (Fig. 1) of the visual disclosure of the light signal system is a geometric model, but without taking into account the factors that determine the effectiveness of the visual search:

\section{- brightness of the background;}

- transparency of the atmosphere;

- Condition of the observer's adaptation;

- Search time.

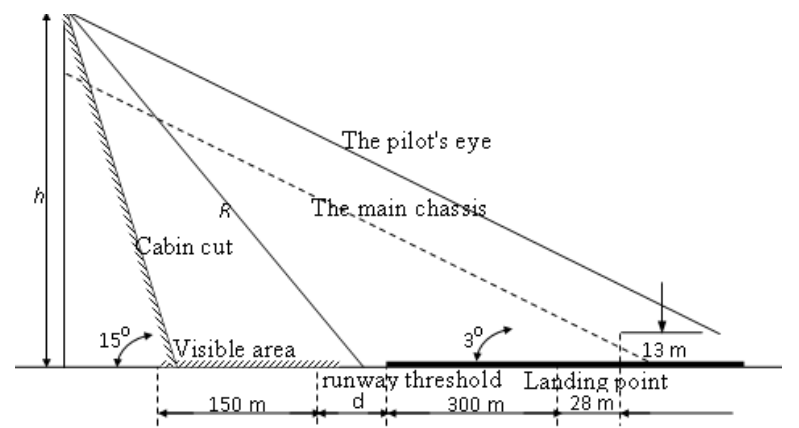

Fig. 1. Geometric dimensions at the final stage of approach: $\mathrm{R}$ is visual range to the most remote fire of area; $h$ is the height of level of the pilot's eye; $d$ is the distance from the end of the visible area to the runway threshold

In night conditions and dense fogs (landing airplane for II and III categories), the second component has an advantage - it determines both the background brightness and the observer's adaptation. Thus, aerodrome fires are the objects of search, which determine the conditions of the visual work of the pilot.

In accordance with [1], the visibility of the fires depends on the limiting illumination on the retina of the eye, which is determined by Alard's law:

$$
\mathrm{E}=\left(\mathrm{I} / \mathrm{R}^{2}\right) \bullet \tau^{\mathrm{R}}
$$

where $E$ is the illumination created by the lighting device at a distance $R ; \tau$ is specific transmittance of the atmosphere (transmittance of atmospheric layer thickness of unit length); $R$ is the distance between the light-signaling device and the observer.

If the illumination of the retina of the eye is equal to the limiting illumination, (it is the minimum illumination which causes the visual sensation), then the studied fire can be seen and the distance $\mathrm{R}$ is the visual range of the visibility of this fire. The value of the minimum illumination used to determine the visual range of the visibility of light signals depends on the brightness of the background against which a light signal is observed.

According to the current normative documents, the criterion of aerodrome fire failure of the light-signal system is a reduction of light intensity by more than $50 \%$, which for different subsystems of aerodrome fires will be 10000 to $1250 \mathrm{~cd}$ (for categorical light-signal landing systems) and 100 to $50 \mathrm{~cd}$ (for non-categorical systems). At the same time, the values of light intensity, calculated by the expression (1) for the worst, but admissible observation conditions for this category of landing system will be lower. This means that light signals will be observed at the distance exceeding the distance of the required visual contact. It is clear that the excess of light intensity of fires beyond the limit value is explained by the desire to increase the safety of flights.

Consider that the visual system gives a person up to $90 \%$ of all accepted information. Obtaining information about the outside world with the help of vision can always be considered as a sequential or simultaneous solution of the problem. Such problems may be related to search and location of the object. Under certain conditions, the eye cannot separate the object. In this case, it is said that the object is below the threshold of visual perception and the probability of observation is zero. Under other conditions, the eye instantly clearly recognizes the object - in this case, the probability of observation is $100 \%$. It is clear that there is an area beyond which one can speak about this or that degree of probability for the correct solution of the visual problem. That is, the solution of the visual problem is possible in cases when the conditions of visibility exceed the threshold values of illumination on the eye apple of the observer, which in our case is the pilot of the aircraft.

The term "visibility" of the object has a fairly broad interpretation and is related with meteorological conditions, in particular with atmospheric optics, light engineering, physiological optics, and others.

It is known that the visual perception of point light sources, which includes aerodrome fires of the light-signal system, is determined by their shine. The location of the aerodrome fire is most often known if the aerodrome fire is located in some line of sight. To find the object related with its search, the shine of the point object should be greater than the threshold value of $\mathrm{E}_{\mathrm{thr}}=2 \cdot 10^{-8} \mathrm{~lx}$ at a brightness of the background of $10^{-6} \mathrm{~cd} / \mathrm{m}^{2}$, and the more the probability of its finding, the less search time.

Dependence of threshold illumination from the brightness of the background is a continuous function approximated by the expression:

$$
\log \mathrm{E}_{\mathrm{thr}}=0,05\left(\log \mathrm{L}_{\mathrm{bgr}}\right)^{2}+0,57 \log \mathrm{L}_{\mathrm{bgr}}-6,66
$$

where $E_{t h r}$ is threshold illumination, lx; $L_{b g r}$ is the brightness of the background, $\mathrm{cd} / \mathrm{m}^{2}$.

Consider that at the stage of visual piloting, for a sure visual contact of a pilot with a light-signal system, aerodrome fires should create in the plane of the eye apple the illumination which is not lower than the threshold. The distance to the fires at the beginning of visual piloting depends on many factors, but the number of these values is reduced to four depending on the category of radio-lighting equipment landing. The influence of the factors of atmosphere transparency is taken into account by the value of the specific transmittance, which varies from 0.9 to $10^{8.5}$.

The obtained information can be considered with the help of vision as a series of problems of search and finding of the object, recognizing it by a number of features (form, color, presence of details, etc.), that is, visual problems.

It is clear that there is an area for which one can speak about this or that degree of confidence of the correct solution of the visual problem. The main factors determining the visibility of aerodrome fires in their visual search in the atmosphere are:

- contrast of the object of observation with the background;

- light power of the fire; angular field of overview;

- $\quad$ search time; transparency of the atmosphere;

- $\quad$ object speed; probability of detection;

- $\quad$ state of observer adaptation. 
Yu. Kvach, Вип.55, №02.

Presence of other objects in the line of sight also affects the detection of the considered object etc.

The probability of detecting point objects is determined by the expression [3]:

$$
\mathrm{P}=1-\exp \left(-\left(\mathrm{a}_{\mathrm{b}} \cdot \mathrm{E}^{2} \bullet \mathrm{t}\right) /(2 \beta)^{2} \mathrm{~L}^{2 \mathrm{n}}\right),
$$

where $P$ is probability of detection; $a$ is coefficient characterizing the individual characteristics of the observer. According to the results of experiment for binocular vision follows that $a_{b}=2,6 \cdot 10^{14} \mathrm{deg}^{2}\left(\mathrm{~cd} / \mathrm{m}^{2}\right)^{2} 1 \mathrm{x}^{-2} \mathrm{~s}^{-1}$, for monocular vision $a_{m}=1,8 \cdot 10^{14} \mathrm{deg}^{2}\left(\mathrm{~cd} / \mathrm{m}^{2}\right)^{2} 1 \mathrm{x}^{-2} \mathrm{~s}^{-1} ; E$ is illumination in the plane of the eye apple of the observer from the point source of light, lx; $t$ is search time, s; $2 \beta$ is the angular field of the search, deg; $L$ is background brightness, $\mathrm{cd} / \mathrm{m}^{2} ; n$ is a coefficient depending on the brightness of the background and is calculated by the empirical formula:

$$
\mathrm{n}=0,6+0,1 \cdot \lg \mathrm{L}
$$

within brightness change:

$10^{3} \mathrm{~cd} / \mathrm{m}^{2}<L<30 \mathrm{~cd} / \mathrm{m}^{2}$,

if $L>30 \mathrm{~cd} / \mathrm{m}^{2}$ then $n=0.75$

if $10^{-6} \mathrm{~cd} / \mathrm{m}^{2}<L<10^{-3} \mathrm{~cd} / \mathrm{m}^{2}$ then $n=0.3$.

We can determine the necessary illumination in the plane of the eye apple, if we specify some values of the listed quantities and then using the inverse squares law we may find the observation distance of the fire on which it fire will be detected with probability $P$.

\section{PRoposed Algorithm OF Aided ClassificAtion OF GROUND OBJECTS}

To solve this complex task, a toolkit using the interface MATLAB $[4,5]$ is proposed to determine the illumination created by a separate fire or group of aerodrome fires of aerodrome light systems, depending on the input data (Fig. 2) $[6]:$

1) coordinates $(\mathrm{X}, \mathrm{Y}, \mathrm{Z})$ and angles $(\mathrm{V}, \mathrm{G})$ of the location of aerodrome light signal fires on the runway;

2) photometric data of aerodrome light signal fires by calling ies-files of respective fires [7];

3 ) coordinates of the observer position in relation to the light-signal picture for determining the length of the trajectory between the light emitter and the receiver;

4) parameters characterizing the complexity of meteorological conditions with indicating the background brightness ( $\left.\mathrm{L}_{\text {bock}}\right)$, atmospheric transparency and meteorological range of visibility.

Toolkit allows to get:

- illumination, taking into account the cosine dependence created by aerodrome fires on the pupil of the observer $\left(\mathrm{E}_{0}\right)$;

- illumination by Allard, created by aerodrome fires at the observer's pupil $\left(\mathrm{E}_{\mathrm{A}}\right)$;

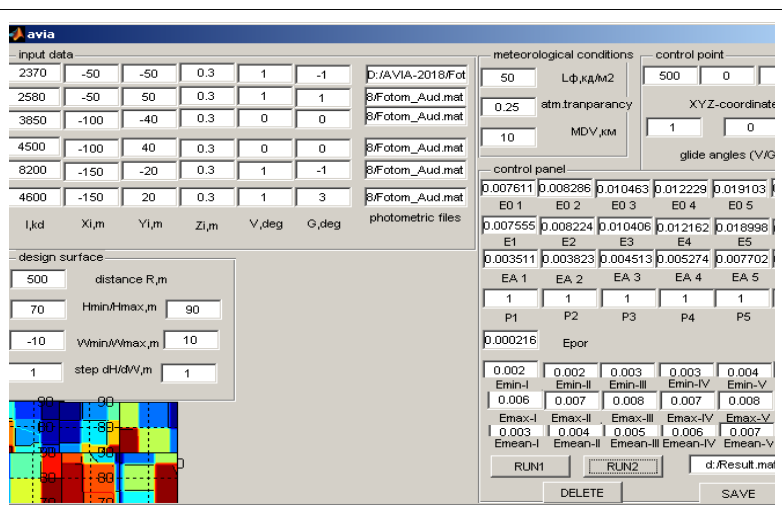

Fig. 2. Toolkit for determining the visual recognition of light-signal systems element of aerodromes, depending on the glide path angle of piloting, individual characteristics of the observer, transparency of the atmosphere.

- total illumination created by aerodrome fires at the pupil of the observer (E) with the definition of minimum, average and maximum value;

- the threshold value of illumination, which allows to estimate the visibility of aerodrome fires, depending on complex meteorological conditions;

- a graphic representation of the illumination from each individual aerodrome fire (Fig. 3);

- graphic representation of illumination from a group of aerodrome fires;

- graphic representation of the direction of radiation of aerodrome fires (Fig. 4).

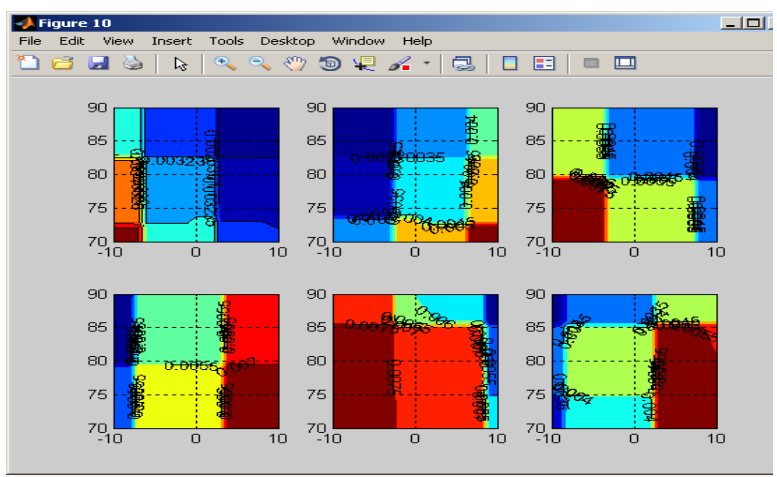

Fig. 3. A graphic representation of the illumination of the studied fires

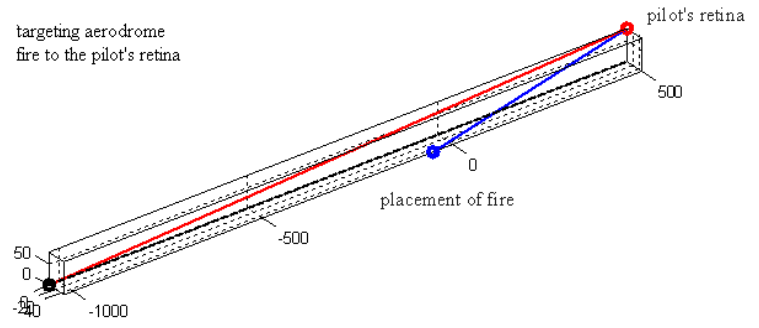

Fig. 4. The created graphic image of contribution of targeting individual fire with corresponding light intensity at the observer targeting aerodrome fire to the pilot's retina 
Graphic images of the orientation of a separate aerodrome fire or a group of fires with a corresponding light intensity on the observer allows to make conclusions about their contribution to the overall picture of visual perception by the pilot.

Thus, the modeling of the illumination created on the retina of the pilot's eye takes place taking into account the brightness of the background, on which individual fires or a group of fires, depending on the location coordinates and their photometric characteristics, in the complex meteorological conditions are recognized.

\section{Conclusions}

The aerodrome lights are visible as a result of the simulation of the effect of the atmosphere transparency, coordinates and angles of the location of aerodrome lights on the observation of light-signal lights at a distance of 500 meters, since the value of the illumination created at the pupil of the observer exceeds the threshold value of illumination.
Thus, the presented toolkit in the MATLAB environment takes into account the factors influencing the observation during the visual search of aerodrome fires of light signal systems from the meteorological range of visibility, which shortens the time to determine the illumination created on the retina of the eye from the aerodrome fire, as well as determine the contribution of remote light sources for general information to get the pilot's visual sensations during approach in difficult meteorological conditions.

\section{REFERENCES}

[1] Doc 9157-AN / 901 ICAO Aerodrome Design Guide. Ч 4. Visual means. 4th ed. - ICAO - 2004. - $182 \mathrm{p}$.

[2] ICAO Doc 9328-AN / 908 "Guide on the Practice of Tracking and Tracking Visibility on Runway Tracking" 3rd ed. - ICAO - 2005. $124 \mathrm{p}$.

[3] Travnikova N. Efficiency of visual search. - M .: Mechanical Engineering, 1985. - 128p

[4] Kondrashov V., Korolyov S. MathLab as a system of programming scientific and technical calculations, Mir, Institute of Strategic Stability of the Ministry of Atomic Energy of the Russian Federation, 2002.

[5] Badriev I.B., Banderov V.V., Zadvornov O.A. Development of a graphical user interface in the MathLab environment. Tutorial, Kazan State University, - 2010. - 113 p.

[6] Kvach Yu.M. Modeling the influence of factors on the monitoring of the light-signal fires of the civil aviation aerodrome in matlab environment / Electronics and control systems. - 2018. - № 4(58) C.118 - 123 .

[7] Kvach Yu.M. Modeling of aerodrome light-signal lights in simulators of the visual environment of aviation simulators / Bulletin of the National Aviation University. - 2007. - № 1 - C.55 - 58.

\title{
Моделювання освітлення на сітківці ока пілота під час пілотування в складних метеорологічних умовах у середовищі MATLAB
}

\author{
Ю. Квач, \\ Національний авіаційний університет \\ Україна
}

\begin{abstract}
Розглянуто моделювання фрагментів світлосигнальної картини в умовах різкого дефіциту часу на етапі візуального пілотування повітряного корабля в складних метеорологічних умовах. Пропонується можливість ідентифікувати потенційні ризики шляхом моделювання в середовищі MATLAB, щоб в разі необхідності вжити заходів для зменшення ймовірності виникнення авіаційної події за рахунок керування надійністю світлосигнальної системою аеродрому. Використання інструменту в інтерфейсі MATLAB дозволяє проводити моделювання освітленості, створюваної на сітківці ока пілота від аеродромних вогнів 3 урахуванням місцезнаходження (координат) спостерігача, метеорологічних умов і розміщення сусідніх аеродромних вогнів для можливості управління і зниження ризику до прийнятного рівню для запобігання авіаційних подій. Представлений інструментарій в середовищі MATLAB враховує домінуючі фактори, що впливають на спостереження під час візуального пошуку аеродромних вогнів світлосигнальних систем в залежності від метеорологічної дальності видимості, що дозволяє скоротити час на визначення освітленості, створюваної на сітківці ока від аеродромного вогню, а також визначити внесок віддалених джерел світла на загальну інформацію для отримання зорових відчуттів пілота під час заходу на посадку в складних метеорологічних умовах. Метрика зорових відчуттів під час заходу на посадку в складних метеорологічних умов залишається актуальною. Тому надана можливість моделювати світлосигнальну картину в інтерфейсі MATLAB для зручного використання інструментарію щодо визначення візуального пошуку аеродромних вогнів на аеродромах цивільної авіації з урахуванням координат при заході на посадку спостерігача і прозорості атмосфери.
\end{abstract}

Ключові слова - спостереження; моделювання фрагментів світлового сигналу; візуальний пошук; розпізнавання вогнів на аеродромах, надійність світлосигнального забезпечення, керування ризиком, ймовірності виникнення авіаційної події, освітленність на сітківиі ока, хоровы выдчуття, працездатність аеродромних вогнів, прийнятний рівень, складні метеорологічні умови, домінуючі фактори, метеорологічна дальність видимості. 